\title{
A radiographic survey of monumental masonry workers in Aberdeen
}

\author{
T. A. LLOYD DAVIES, A. T. DOIG, A. J. FOX, and M. GREENBERG \\ Medical Services Division, Department of Employment, 1/13 Chepstow Place, London W2
}

\begin{abstract}
Lloyd Davies, T. A., Doig, A. T., Fox, A. J., and Greenberg, M. (1973). British Journal of Industrial Medicine, 30, 227-231. A radiographic survey of monumental masonry workers in Aberdeen. A survey of radiographic appearances of the lungs of monumental masonry workers in Aberdeen was carried out to determine the present prevalence of abnormalities and to serve as a standard for future comparisons in view of changes in methods of working. No major change could be detected in the status of these granite workers in Aberdeen over the past 20 years but the different methods of survey used by Mair in 1951 and by the present study did not allow of strict comparison. Chest radiographs were reported on by three readers independently using the National Coal Board elaboration of the ILO classification and a score was given to each film using Oldham's method. Multiple regression analysis showed that $x$-ray changes were related to years in granite but progression was slow in comparison with foundry workers. The prevalence of radiographic appearances of category 1 or greater was $3.0 \%$ overall and $4.6 \%$ for workers in dusty jobs. Evidence of pneumoconiosis was not observed in workers exposed for less than 20 years.

With the environmental control attained the threshold limit values for respirable dust were not often much exceeded.
\end{abstract}

In his survey of Aberdeen monumental stonecutters, Mair (1951) considered $9.9 \%$ to have abnormal chest radiographs though only $2.1 \%$ had silicosis of severe degree (nodulation, massive shadows or silicosis and tuberculosis). The dread of silicosis that had assumed sinister proportions among lay and medical people in Aberdeen at that time he considered to be overrated and a carry-over from the days when there was a higher rate of tuberculosis associated with 'closed group' conditions.

In recent years conditions have been altering. Local exhaust ventilation which might ameliorate the hazard has been installed but, on the other hand, enclosure of the work sheds which may increase the hazard is more frequent. Moreover imports of granite into Aberdeen, which had begun before 1900 and just before the second world war constituted $80 \%$ of the stone used, have varied widely over the past 40 years (Hamilton, 1963). A number of imported 'granites' have a quartz content below $5 \%$. If the relative amount of such low silica granite used increased, the risk from the fibrogenic dust might be expected to decline. In 1970 the system of Cameron ${ }^{1}$ exhaust ventilation was being developed and at the same time most work sheds were being enclosed; it was therefore decided to make a radiographic study of the chests of monumental masons in Aberdeen to assess the prevalence of silicosis and to provide a base line for future studies of methods of dust control.

\section{Method}

A preliminary nominal roll was completed for all workers employed at the 19 member firms of the Aberdeen Granite Association on 1 September 1970. From this roll four subjects were removed because they had left the industry after having worked in it for only a matter of weeks. A further 19 were not included in the survey:

${ }^{1}$ This employs a high volume suction hood which is counterbalanced and consequently easy to position adjacent to the handwork being carried out. 
$15^{1}$ declined to be $x$-rayed, three were absent due to sickness when radiography was carried out and were subsequently unavailable, and one had left the district and was untraceable. A total of 469 workers were studied by means of an occupational history (in which all jobs since leaving school were recorded) and a full-plate postero-anterior chest radiograph.

Workers' occupations were classified according to their main job carried out during total service in the granite industry. If they had been employed for twothirds or more of their granite working time in one particular job this was given as the main occupation. If less than two-thirds of the working life had been spent in one particular job, the man was classified as a mixed worker.

Occupations were also classified as dusty or non-dusty on the basis of inspection. The former include masons, letter cutters, shot blast operators, and turners who work 'dry'; the latter, cutters (sawyers) and polishers, whose work requires a plentiful supply of water, labourers, and cranemen. Where a worker had spent any portion of his working life in a dusty trade he was classed as a dusty worker.

Chest radiographs were first scrutinized for clinical action; one case of carcinoma of the bronchus and two cases of tuberculosis were identified requiring further investigation. The radiographs were subsequently scored independently by three readers using the modification of the ILO classification (International Labour Office, 1959) proposed by Liddell (1963) (now known as the NCB Elaboration).

Four yards were selected as representative of the industry following a preliminary survey by H.M. Inspectorate of Factories Industrial Hygiene Laboratory. Mass concentrations of dust produced by some workers using pneumatic tools were measured by Casella size selective personal samplers, which ran throughout one day, giving a time-weighted average personal exposure. Background exposure of total mineral dust was measured using either Hurricane or Rotheroe Mitchell high volume gravimetric samplers, which also enabled a quartz determination to be carried out.

Their years of exposure in the industry ranged from 13 to 45 mean 30.3 years) and ages 32 to 64 (mean 54.1 years).
TABLE 1

Numbers Employed in Various Occupations

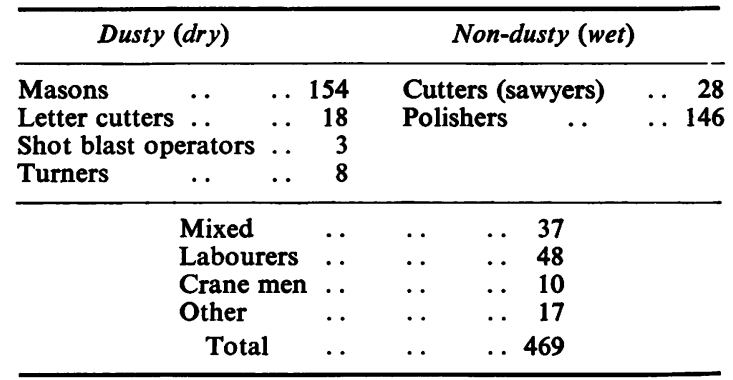

\section{Results}

Table 1 lists the jobs of workers at the time of the survey. The numbers of men in dusty and non-dusty occupations were 262 and 207 respectively: the years of employment in the industry at the time of the survey (Table 2) were similar for the two groups.

\section{Radiographic results}

Table 3 shows the distribution of categories recorded by each of the three readers. Reader $B$ placed more $x$-rays in categories $0 / 1$ and $1 / 1$, and fewer in category $0 / 0$, than did the other two readers. Reader C placed fewer in categories $2 / 1$ and $2 / 2$.

Individual readings on the NCB/ILO scale were calculated, together with a score on Oldham's $\mathrm{x}$-scale (1971). The cumulative distribution of the total was plotted on normal probability paper against the scale of $y$ according to Oldham's method.

In Table 4, the scores on the x-scale of the midpoints of categories are calculated and appropriate weights derived.

The population scores are summarized in Table 5. Seventy-one per cent were classified by all three readers as $0 / 0$. The average score on the $x$-scale was $\mathbf{0} \cdot 3883$.

TABLE 2

Distribution of Years of Granite Work against Category of Silicosis

\begin{tabular}{|c|c|c|c|c|c|c|}
\hline \multirow{2}{*}{$\begin{array}{l}\text { Years of } \\
\text { work in } \\
\text { granite } \\
\text { industry }\end{array}$} & \multicolumn{2}{|c|}{$\begin{array}{l}\text { Numbers of } \\
\text { granite workers }\end{array}$} & \multicolumn{2}{|c|}{ Category 1} & \multicolumn{2}{|c|}{ Category 2} \\
\hline & Total & (Dusty ${ }^{1}$ workers) & Total & (Dusty ${ }^{1}$ workers) & Total & (Dusty1 workers) \\
\hline $\begin{array}{c}0-9 \\
10-19 \\
20-29 \\
30-39 \\
40+ \\
\text { Total }\end{array}$ & $\begin{array}{r}125 \\
85 \\
94 \\
120 \\
45 \\
469\end{array}$ & $\begin{array}{r}(57) \\
(53) \\
(61) \\
(67) \\
(24) \\
(262)\end{array}$ & $\begin{array}{r}- \\
3 \\
5 \\
2 \\
10\end{array}$ & $\begin{array}{l}(-) \\
(-) \\
(3) \\
(4) \\
(1) \\
(8)\end{array}$ & $\begin{array}{l}- \\
\overline{-} \\
1 \\
3 \\
4\end{array}$ & $\begin{array}{l}(-) \\
(-) \\
(-) \\
(1) \\
(3) \\
(4)\end{array}$ \\
\hline
\end{tabular}

'See text for definition. 
TABLE 3

Distribution of X-Ray Readings

\begin{tabular}{|c|c|c|c|c|c|c|c|c|}
\hline \multirow[b]{2}{*}{$\begin{array}{l}\text { Cat- } \\
\text { egory }\end{array}$} & \multicolumn{2}{|c|}{ Reader $A$} & \multicolumn{2}{|c|}{ Reader $B$} & \multicolumn{2}{|c|}{ Reader $C$} & \multicolumn{2}{|c|}{ Total readings } \\
\hline & No. & $\%$ & No. & $\%$ & No. & $\%$ & No. & $\begin{array}{c}\text { Cumu- } \\
\text { lative } \\
\%\end{array}$ \\
\hline $\begin{array}{l}0 /- \\
0 / 0 \\
0 / 1 \\
1 / 0 \\
1 / 1 \\
1 / 2 \\
2 / 1 \\
2 / 2 \\
2 / 3\end{array}$ & $\begin{array}{r}416 \\
30 \\
3 \\
4 \\
3 \\
5 \\
4\end{array}$ & $\begin{array}{r}89 \\
6 \\
1 \\
1 \\
1 \\
1 \\
1\end{array}$ & $\begin{array}{r}383 \\
52 \\
3 \\
24 \\
3 \\
3\end{array}$ & $\begin{array}{r}82 \\
11 \\
1 \\
5 \\
1 \\
1\end{array}$ & $\begin{array}{r}418 \\
40 \\
5 \\
3 \\
2 \\
1 \\
-\end{array}$ & $\begin{array}{r}89 \\
9 \\
1 \\
1 \\
- \\
-\end{array}$ & $\begin{array}{r}1217 \\
122 \\
11 \\
31 \\
5 \\
9 \\
7\end{array}$ & $\begin{array}{r}86.80 \\
95.50 \\
96.29 \\
98.50 \\
98.86 \\
99.50 \\
100.00\end{array}$ \\
\hline $\begin{array}{l}\text { Totals } \\
\text { Not } \\
\text { read }\end{array}$ & $\begin{array}{r}465 \\
4\end{array}$ & 100 & $\begin{array}{r}468 \\
1\end{array}$ & 101 & 469 & 100 & 1402 & \\
\hline
\end{tabular}

A multiple regression analysis was carried out on the data. The 'score' was considered as the dependent variable and the best subset of independent variables was selected from 'constant term', 'age of entry into granite', 'years in granite', and 'years in

TABLE 4

Derivation of X-Ray Scores by Method PROPOSED BY OLDHAM (1971)

\begin{tabular}{c|c|c|c|c}
\hline Category & $\begin{array}{c}\text { Borders on } \\
\text { the } \\
y \text {-scale }\end{array}$ & $\begin{array}{c}\text { Borders on } \\
\text { the } \\
x \text {-scale }^{\mathbf{2}}\end{array}$ & $\begin{array}{c}\text { Mid-point } \\
\text { on } \\
x \text {-scale }\end{array}$ & $\begin{array}{c}\text { Weight } \\
W_{1}= \\
1 / \text { width }^{4}\end{array}$ \\
\hline $0 /-$ & & 0.08 & 0.29 & 2.3809 \\
$0 / 0$ & 0.08 & 0.50 & 0.75 & 2.0000 \\
$0 / 1$ & 1.00 & 1.00 & 1.06 & 8.3333 \\
$1 / 0$ & 1.11 & 1.12 & 1.445 & 1.5384 \\
$1 / 1$ & 1.70 & 1.77 & 1.885 & 4.3478 \\
$1 / 2$ & 1.94 & 2.00 & 2.195 & 2.5641 \\
$2 / 1$ & 2.36 & 2.39 & 2.695 & 1.6393 \\
$2 / 2$ & 3.20 & 3.00 & & \\
\hline
\end{tabular}

${ }^{1}$ The borders on the y-scale are derived by fitting the cumulative distribution function

'The transformation from the $y$ to the $x$ scale is

$$
y=1+1\left(x^{2}-\frac{1}{x^{2}}\right) \text {. }
$$

'The mid-point on the $x$-scale is the score attached to each category.

A weighted average of the readings for a particular film is then obtained using the inverse of the width of categories as the basic for weights
TABLE 5

Summary of X-Ray Readings of the Granite Survey Population by Three Readers

\begin{tabular}{c|ccc|r}
\hline $\begin{array}{c}\text { Score on } \\
x \text {-scale }\end{array}$ & \multicolumn{3}{|c|}{ Combination of grades } & No. \\
\hline 0.29 & $0 / 0$ & $0 / 0$ & $0 / 0$ & 334 \\
0.43 & $0 / 0$ & $0 / 0$ & $0 / 1$ & 73 \\
0.57 & $0 / 0$ & $0 / 0$ & $1 / 1$ & 15 \\
0.58 & $0 / 0$ & $0 / 1$ & $0 / 1$ & 14 \\
0.75 & $0 / 0$ & $0 / 1$ & $1 / 1$ & 7 \\
0.78 & $0 / 0$ & $0 / 0$ & $1 / 0$ & 5 \\
0.87 & $0 / 0$ & $0 / 1$ & $1 / 0$ & 2 \\
0.94 & $0 / 1$ & $0 / 1$ & $1 / 1$ & 2 \\
0.96 & $0 / 0$ & $1 / 0$ & $1 / 0$ & 3 \\
1.05 & $0 / 0$ & $0 / 0$ & $1 / 2$ & 2 \\
$1 \cdot 14$ & $0 / 0$ & $1 / 0$ & $2 / 1$ & 1 \\
1.19 & $0 / 0$ & $0 / 1$ & $1 / 2$ & 1 \\
1.32 & $0 / 0$ & $1 / 1$ & $2 / 1$ & 3 \\
1.34 & $0 / 0$ & $1 / 1$ & $1 / 2$ & 1 \\
1.53 & $0 / 1$ & $1 / 1$ & $2 / 1$ & 2 \\
2.02 & $1 / 1$ & $2 / 1$ & $2 / 1$ & 1 \\
2.23 & $1 / 2$ & $2 / 2$ & $2 / 2$ & 2 \\
2.30 & $1 / 1$ & $2 / 2$ & $2 / 2$ & 1 \\
\hline & \multicolumn{3}{|c|}{ Total } & 469 \\
\hline
\end{tabular}

other dusty work'. (Because of limited sampling of factories, 'dust levels' could not be included in the analysis.) The constant term and the years in granite contributed significantly to the regression giving

$$
\text { Score }=0.2693+0.0055 \times \text { (years in granite) }
$$

The multiple correlation was 0.856 . It should be noted that although other dusty work had no significant role in this regression, one cannot infer that this is true for other surveys. In the present survey, few subjects had been employed for any significant period in dusty work other than that with granite. In summary, the average man enters granite with an $x$-ray score of 0.2693 (standard deviation \pm 0.0209), corresponding to approximately the centre of category $0 / 0$, and progresses at a rate of 0.0055 per year (standard deviation \pm 0.0008 ). This means that it would take more than a working life-time for the average man to progress to category $0 / 1$.

Category 1 silicosis was not seen with less than 20 years of exposure. Category 2 only occurred after a minimum of 30 years' exposure (Table 2). The four subjects with category 2 silicosis were classified as dusty workers. Only two of the non-dusty workers reached category 1 . Two cases of tuberculosis were identified in subjects with category 1 silicosis; one was active, one quiescent.

\section{Dust measurement}

Table 6 lists the results of dust sampling in four factories at 10 sites and relates them to the threshold limit values (Department of Employment, 1971). In 
TABLE 6

Dust MEASURements in Four Factories COMPaRED WITH CALCUlated THRESHOLd Limit VALUES (TLV)

\begin{tabular}{c|c|c|c|c}
\hline $\begin{array}{c}\text { Quartz } \\
\text { content of } \\
\text { total } \\
\text { airborne } \\
\text { dust } \\
(\%)\end{array}$ & $\begin{array}{c}\text { Total } \\
\text { mineral } \\
\text { dust } \\
\text { (back- } \\
\text { ground })^{1} \\
\left(\mathrm{mg} / \mathrm{m}^{3}\right)\end{array}$ & $\begin{array}{c}\text { TLV } \\
\text { total } \\
\text { dust } \\
\left(\mathrm{mg} / \mathrm{m}^{3}\right)\end{array}$ & $\begin{array}{c}\text { Respirable } \\
\text { dust }^{3} \\
\left(\mathrm{mg} / \mathrm{m}^{3}\right)\end{array}$ & $\begin{array}{c}T L V^{2} \\
\text { respirable } \\
\text { dust }^{4} \\
\left(\mathrm{mg} / \mathrm{m}^{3}\right)\end{array}$ \\
\hline 13.4 & 10.05 & 1.8 & 2.1 & 1.5 \\
21.0 & 12.2 & 1.3 & 2.5 & 1.0 \\
Not & 14.6 & - & 8.9 & - \\
detected & & 1.4 & 1.9 & 1.2 \\
19.0 & 8.0 & 5.1 & 1.2 & 3.4 \\
2.8 & 4.0 & 2.0 & 1.9 & 1.6 \\
12.3 & 4.0 & 3.8 & 3.2 & 2.7 \\
5.0 & 3.8 & - & 1.0 & 2.7 \\
5.0 & - & - & 0.5 & 1.1 \\
22.0 & - & - & 1.9 & 1.1 \\
22.0 & - & - & & \\
\hline
\end{tabular}

'Total mineral dust (background) includes 'respirable' and 'non-respirable' dust as measured by high-volume gravimetric sampler at a distance from the working position.

'Threshold limit values (TLV) for 'total dust' and 'respirable dust' quoted are derived using the appropriate formulae (Department of Employment, 1971).

${ }^{3 '}$ Respirable' dust as defined by the British Medical Research Council criteria (Hatch and Gross, 1964) and measured by a Casella size selective personal sampler

Assuming \% respirable quartz is $\frac{1}{3} \%$ airborne quartz content because the per cent respirable quartz content has not been estimated

${ }^{5}$ No local exhaust ventilation during this test

all except one case local exhaust ventilation was being used at the time of sampling. The quartz content of the stone as determined from the total airborne dust measurements ranged from zero to $22 \%$.

The use of exhaust ventilation resulted in a concentration of respirable dust in a narrow range of $1 \cdot 0-3 \cdot 2 \mathrm{mg} / \mathrm{m}^{3}$ in most cases, showing a fairly uniform dispersal and control of dust in the firms investigated. The threshold limit values for respirable dust were not in general much exceeded. Total dust levels, however, were very variable but the tendency was for them to be equal to or in excess of the relevant threshold limit values.

\section{Discussion}

In recent years there have been four other studies of granite workers-Mair (1951) in Aberdeen, Hale and Sheers (1963) in Cornwall and Devon, Ahlmark Bruce, and Nyström (1965) in Sweden, and Gründorfer and Raber (1970) in Austria.

Groups studied by these authors were exposed to granites containing differing free silica contents.
Gründorfer and Raber quoted $18.0 \%$, Ahlmark et al., $35 \%$, and Hale and Sheers 30 to $50 \%$; in the case of Mair's study, a reasonable assumption is that despite heavy imports of granite, some of low free silica content, substantial quantities of granite with $20 \%$ free silica were used. The atmospheric content of granite dust is quoted by Gründorfer and Raber. Calculation from their figures gives a range of approximately $1.9-12.5 \mathrm{mg} / \mathrm{m}^{3}$, the highest level being obtained at a particular crushing plant where 15 of the 18 silicotic subjects worked.

The population studied, and the duration of observation, varied from survey to survey. Mair carried out a single study of monumental masons, some of whom had retired. Hale and Sheers studied granite workers, including masons, and re-examined those still at work 10 years later when contraction of the industry, death, and retirement had reduced their number.

Ahlmark et al. were uncertain of the size of the population at risk but estimated the number of workers in particularly dusty work; they reported cases of silicosis occurring in this population between 1945 and 1965. Gründorfer and Raber followed a group of workers engaged in producing crushed granite for 10 years, during which time the number of workers available for study fell. Exposure to other occupational dusts, which may have been contributory, was mentioned by all the above authors (except Mair) in association with cases of silicosis.

The evolution of standardized methods for describing the radiographic appearances of pneumoconiosis over the past 20 years has altered what readers are registering: on this basis alone a close comparison of $x$-ray results is not justified. Variations in the number of film readers employed and techniques for assigning a score to films in the various surveys also detract from comparability: the technique of having three readers and combining their scores in this survey reduces observer error and assists future comparability. Comparison with pneumoconiosis in other occupations was attempted by Ahlmark et al. (1965), studying severity and rate of progression. They concluded that silicosis in granite workers was comparable with that in steel fettlers and showed a strong tendency to progression. Comparing the granite workers in our survey with foundry floor workers and fettlers in a study carried out by Davies (1971), using similar epidemiological techniques for scoring and analysis, granite workers apparently have a slow rate of progression, only a small percentage passing beyond the borders of category $0 / 1$. If Table 5 of this paper is compared with Table 27 of Davies (1971) the difference is apparent: in granite workers $97 \%$ are in category 0 , compared with $45.8 \%$ of fettlers in ferrous foundries. Comparing Swedish granite workers with Swedish coal miners, Ahlmark et al. concluded that pro- 
gression is greater in the former. In Great Britain (Department of Trade and Industry, 1972) $3 \cdot 1 \%$ to $24.2 \%$ of miners have category 1 or greater pneumoconiosis. Comparable figures for granite workers (this survey) are $3 \%$ for all occupations, or $4.6 \%$ for 'dusty' workers. Hale and Sheers (1963) considered $14.3 \%$ of their granite workers to have category 2 or 3 silicosis or progressive massive fibrosis. We found only $1.4 \%$ to have category 2 silicosis and none category $3:$ this disparity is difficult to explain.

Gründorfer and Raber associated the major risk in their industry with one specific working place where 15 of their cases of silicosis were employed.

Mair (1951) observed that silicosis in Aberdeen granite workers had an onset late in life and progressed slowly. The position does not appear to have altered significantly with the various changes of mechanization, enclosure, and ventilation. Our survey shares the weakness of most prevalence studies in that it is based on a survivor population. The subjects declining examination in this survey did not differ in terms of age and duration of exposure from those entering the study. It is possible that a higher proportion of these workers refused to have their chests $x$-rayed because of known or suspected chest illness and a fear of loss of employment. Medical histories and previous chest radiographs, however, were not available as evidence to test this hypothesis.

Different conclusions reached in various surveys of granite workers might be attributable to differences in environmental hygiene, differences in free silica content of the stone worked, differing years of exposure in the populations studied, the characteristics of workers declining examination or the prevalence of tuberculosis.

We are grateful to Dr. J. Black of the Pneumoconiosis Medical Panel, Glasgow for help with film reading; to H.M. Factory Inspectorate, Industrial Hygiene Laboratory for dust estimations; to Dr. John Young and staff of the Chest Radiography Centre, North East Regional Hospital Board (Scotland) for willingly solving the tech- nical and work load problems presented by the survey; to the Aberdeen Granite Association and the Amalgamated Union of Building Trade Workers and their members for their co-operation; and to Mr. A. Gow, Mr. D. Lindsey, and Mr. W. Mortimer of H.M. Factory Inspectorate who facilitated the survey.

\section{References}

Ahlmark, A., Bruce, T., Nyström, $\AA$. (1965). Silicosis from quarrying and working of granite. British Journal of Industrial Medicine, 22, 285-290.

Davies, T. A. Lloyd (1971). A Survey of Respiratory Disease in Foundrymen, p. 41. H.M.S.O., London.

Department of Employment (1971). Threshold Limit Values for 1971. Technical Data Note 2/71, p. 12. H.M.S.O., London.

Department of Trade and Industry (1972). Digest of Pneumoconiosis Statistics, 1970, p. 17. H.M.S.O., London.i

Gründorfer, W., and Raber, A. (1970). Progressive silicosis in granite workers. British Journal of Industrial Medicine, 27, $110-120$.

Hale, L. W., and Sheers, G. (1963). Silicosis in west country granite workers. British Journal of Industrial Medicine, 20, 218-225.

Hatch, T. F., and Gross, P. (1964). Pulmonary Deposition and Retention of Inhaled Aerosols, p. 149. Academic Press, New York.

Hamilton, Henry (1963). The North East of Scotland. A survey prepared for the Aberdeen meeting of the British Association for the Advancement of Science 1963, p. 165. Published by the Local Committee, Aberdeen.

International Labour Office (1959). Meeting of experts on the international classification of radiographs of the pneumoconioses, 1958. Occupational Safety and Health, 9, No. 2, 63-69. I.L.O., Geneva.

Liddell, F. D. K. (1963). An experiment in film reading. British Journal of Industrial Medicine, 20, 300-312.

Mair, A. (1951). A survey of the granite industry in Aberdeen with reference to silicosis. Edinburgh Medical Journal, 58, 457-480.

Oldham, P. D. (1971). Numerical scoring of radiological simple pneumoconiosis. In Inhaled Particles III. Proceedings of British Occupational Hygiene Society Symposium, London 1970, edited by W. H. Walton, pp. 621-632. Unwin, Old Woking.

Received for publication 26 June, 1972. 